\title{
REPRESENTAÇÕES ACERCA DA ESCOLA PÚBLICA E DAS PRÁTICAS DE ESCOLARIZAÇÃO NAS OBRAS LITERÁRIAS DE DALCIDIO JURANDIR: TECENDO ANÁLISES PARA SE COMPREENDER AS RELAÇÕES DE PODER E DE CLASSES EM BELÉM-PA
}

\author{
Leticia Souto Pantoja \\ Universidade Federal do Pará (UFPA) \\ lspantoja@ufpa.br
}

\begin{abstract}
RESUMO
A partir da análise dos livros "Belém do Grão-Pará" e "Passagem dos Inocentes" escritos pelo literato Dalcídio Jurandir discute-se as relações de poder e de classes entretecidas na sociedade parauara entre os anos de 1920 e 1940. Ativo militante de esquerda, integrante dos quadros da secretaria estadual de educação e colaborador de jornais e revistas da região norte, esse letrado expressou em suas narrativas fortes criticas à escola e as práticas de escolarização vigentes na época. Para ele, a educação escolar pública, ao constituir-se espaço para aquisição de saberes abstratos, desconectados das vivências dos educandos e imbuída de forte sentimento religioso, reforçava as diferenças de classe e afastava a instituição daquilo que o mesmo considerava ser função do conhecimento escolar: contribuir para o processo de construção de uma sociedade justa, formada por indivíduos críticos e reflexivos. Nesse sentido, os escritos dalcidianos acerca da escola e da escolarização são recheados de personagens que exprimem sentimentos contraditórios, desejosos por educar-se para ascender socialmente, mas temerosos diante da vivência escolar, descrita como dispendiosa e autoritária. Assim, em conjunto com outros textos produzidos por esse escritor contidos em revistas destinadas aos professores da rede pública estadual, essas narrativas literárias possibilitam refletir não somente a respeito do universo escolar do período, como também sobre tensões que existiam entre diferentes projetos de sociedade.

Palavras-chave: Dalcidio Jurandir, Escola Pública, Representação, Classes Sociais
\end{abstract}

\section{REPRESENTATIONS ABOUT THE SCHOOL OF PUBLIC AND PRACTICES OF SCHOOLING IN LITERARY WORKS DALCÍDIO JURANDIR: WEAVING ANALYSIS TO UNDERSTAND THE RELATIONSHIP OF POWER AND CLASS IN BELÉM-PA}

\begin{abstract}
From an analysis of the books "Belém do Grão-Pará" and "Passagem dos Inocentes", written by the literate Dalcídio Jurandir, we discuss relations between power and the interwoven classes in the society form Pará from 1920 through 1940. Dalcídio was an active militant on the left, employee in State Education Secretariat and collaborator in newspaper and magazines, in which he exposes strong criticism about the school and the schooling practices in that epoch. According to him, the public school education was an environment of acquisition of abstract knowledge disconnected of student's life and with strong religious feelings and it reinforced the differences among classes and moved the institution away from the thought he had about the function of school knowledge: contribute to the process of construction of a fair society, formed by critic and reflexive individuals. This way, Dalcídio's writings concerning to school and schooling have many characters who express contradictory feelings; they have a desire to study to ascend
\end{abstract}


socially, however afraid about the school life, since it was described as expensive and authoritative. Thus, those literary narratives, together with other texts written by the author for magazines destined to teachers from public schools, give us opportunity to reflect not only about the school universe of that period, but also about tensions that exist in different projects of society.

Keywords: Dalcídio Jurandir, Public School, Representation, Social Status.

\title{
Dalcidio Jurandir e o discurso sobre a educação escolar na Amazônia: algumas aproximações
}

Pensar a obra de Dalcidio Jurandir numa perspectiva histórica constitui significativo desafio de pesquisa, na medida em que os escritos dalcidianos de caráter literário articulam à natureza narrativa do texto ficcional relatos sobre os modos de vida, práticas culturais e aspectos pitorescos que permeiam os valores e as subjetividades do homem amazônida.

Nesse sentido, os romances dalcidianos recheados de evocações e referências sobre os aspectos sociais, educacionais, culturais e políticos prevalentes na região parauara durante os anos em que as obras foram escritas ou aos quais se reportam, possibilitam de forma articulada à leitura de outras fontes -especialmente periódicos e legislaçãorecompor fragmentos importantes da história local amazônida durante os anos 1920 e 1940.

Observe-se neste caso que a questão da educação e seu papel na construção das identidades dos sujeitos sociais, se faz presente de forma direta e/ou implícita em todos os 11 (onze) títulos que compõe o chamado Ciclo do Extremo Norte- conjunto de obras escritas por Dalcidio Jurandir para contar a saga do homem Amazônida através da figura de Alfredo, um menino que migra para Belém para continuar sua educação escolar e tornar-se doutor, redimindo sua família interiorana das dificuldades financeiras vivenciadas após a crise do comércio exportador de borracha.

Conforme preleciona FARIAS (2009: p. 32):

\begin{abstract}
"A educação escolar almejada pelo garoto amazônida o levará a caminhos ou descaminhos do "saber formal"? A resposta à questão é observada, unicamente, por meio de uma travessia nas obras do escritor da Amazônia. Os romances, sobretudo o interior dos personagens criados por Dalcídio, colocam, constantemente, os estudos "no colégio" como a excelência do saber."
\end{abstract}

A escola na perspectiva do literato constituía espaço elevado de formação tanto no que se refere à aquisação de saberes codificados de forma escrita quanto no que diz respeito a formação de valores e hábitos de vida. Segundo Dalcidio Jurandir, o grande problema é que a instituição se encontrava sob o domínio de preceitos e normatizações que a afastavam da realidade social em que se inseria e com a qual deveria dialogar. Conforme afirmou em texto publicado na Revista do Professorado Paraense (1935: p. 42):

"Não devemos manter o antagonismo entre a escola e o meio, a educação e a vida. O problema educacional está ligado ao problema da miséria, da fome, da pauperização das massas e da proletarização das populações urbanas e rurais". 
Vemos assim que na obra dalcidiana a educação escolar torna-se personagem tão importante quanto os outros de caráter humano construídos pelo literato; revelando-se como motivo gerador de condutas e práticas de vida, razão justificadora para atitudes especificas que os personagens tomavam diante de questões relacionadas à pobreza, ao gênero e à raça, dentre outras temáticas.

Particularmente, a permanência de Alfredo no sistema escolar institucionalizado por meio do acesso à matricula no Grupo Escolar Barão do Rio Branco em Belém, tornase ao londo das tramas romanescas dos livros que compõe o Ciclo do Extremo Norte, questão central discutida sob vários ângulos.

Sobre a educação formal e institucional debatida por Dalcidio, FARIAS (2009:p.57):

\begin{abstract}
"Em definição breve, é um "tipo" de educação que estabelece processos fixos, intencionais, planejados e estruturados (de aprendizagem) em que, geralmente, a escola segue um programa (currículo) e os alunos necessitam ser avaliados pelos professores, na maioria dos casos, por prova escrita, mensurando-se assim a aprendizagem.

A escola (e somente ela) consistia em espaço de aprendizagens para Alfredo.

$\mathrm{O}$ ambiente escolar enquanto espaço organizado e produtivo reside nos desejos do garoto. Consequentemente, entendo que a representação de "verdadeira educação" do menino, se faz com a instituição escola."
\end{abstract}

Destes aspectos decorre a importância de se pesquisar as representações dalcidianas acerca da educação escolar pública e das práticas de escolarização. Tal debate constitui recurso interessante para se compreender um pouco mais acerca das relações de poder e conflitos de classe que se processavam na região no período já indicado anteriormente.

Neste artigo discutiremos tão somente as representações acerca da escola pública e das práticas de escolarização contidas nas obras "Belém do Grão Pará"\& "Passagem dos Inocentes" escritas pelo literato Dalcidio Jurandir entre os anos de 1930 e 1950, as quais se reportam ao período correspondente aos anos de 1920 a 1930.

O romance Belém do Grão Pará é o quarto título publicado por Dalcidio Jurandir dentre as dez obras que compõem o Ciclo do extremo Norte. Nele o autor acompanha a transferência do menino Alfredo da ilha do Marajó, região interiorana do estado do Pará, para a cidade de Belém, capital da região.

Por desejo dos pais, Alfredo é obrigado a continuar os estudos que iniciara de forma rudimentar na Vila de Cachoeira ${ }^{1}$, transferindo-se para escolas belemitas consideradas mais aparelhadas e providas de um corpo de profissionais qualificados; leiase, professores que freqüentaram a conhecida "Escola Normal".

Diante da impossibilidade financeira da família mudar-se para a capital, sua mãe se sujeita a hospedá-lo com uma família aparentada e pertencente à pequena classe média decadente, os Alcântara ${ }^{2}$. Acredita-se que toda a ação do romance se desenvolva na década de vinte, mais precisamente a partir do ano de 1922, em virtude das esparsas, mas incisivas alusões que o texto faz a fatos históricos regionais e acontecimentos políticos nacionais.

$\mathrm{O}$ enredo começa com a chegada de Alfredo à Belém, ainda desconfiado e com traços de matutice ou como diria o próprio personagem, "de Tio Bimba" ${ }^{3}$. A partir daí, a história transcorre nessa cidade, fundada nas descrições e narrativas do autor acerca das vivencias que o menino constrói nos múltiplos espaços citadinos e em face de sua interlocução com diferentes sujeitos e contextos sociais. 
Em "Passagem dos Inocentes" o menino vivencia seu segundo ano na capital do estado, passando então a residir com uma sobrinha de seu pai, D. Celeste ou simplesmente Cecé, moradora de uma palhoça na Passagem Mac-Donald localizada em área suburbana de Belém.

Neste novo romance amplia-se o número de personagens dalcidianos que oscilam entre a vida urbanizada e as memórias de suas vivências no Marajó, surgindo figuras como Belerofonte, filho único de D. Cecé, malcriado e abobalhado; seu Antonino Emiliano, marido de dona Celeste, que a desposou depois de um escândalo que manchara a reputação na moça no Muaná; o velho "espantalho" da esquina do beco, sempre observando; a jovem normalista que morava próximo a barraca de Celeste e que simbolizava todas as pretensões e contradições que Alfredo identificava nas professoras do grupo escolar.

Paralelamente, Alfredo intensifica suas perambulações pelas ruas da cidade, especialmente porque o trajeto entre a Passagem dos Inocentes e o Grupo Escolar Barão do Rio Branco era feito a pé, percorrendo as ruas dos bairros do Umarizal e Nazaré, atravessando a cidade de leste a oeste.

A escola apresentada ao leitor de "Passagem dos Inocentes" oscila entre o lugar da descoberta da primeira paixão platônica da juventude e o espaço de alienação dos sujeitos de sua realidade social, posto que corresponde a uma instituição imersa em conteúdos didáticos, técnicas de ensino e métodos de aprendizagem que pouca -ou nenhuma- relação mantém com o contexto cultural de seus alunos.

Assim, o confronto implícito entre o compromisso moral-familiar de obter uma educação escolar e o desejo íntimo de aventurar-se pela urbe, desvendando seus signos e obtendo conhecimentos pragmáticos que apenas o espaço das ruas e o contato com as gentes do povo possibilitam, revela-se constante ao longo de ambos os romances.

\section{Belém entre os anos de 1920 e 1940: contextualizações necessárias}

Os anos entre 1920 e 1940 assinalaram em Belém um período de grandes mudanças econômicas e culturais. Se por um lado a cidade e a região vivenciavam os efeitos do declínio do comércio extrativista do látex, por outro assistiam a emergência de novas práticas de sociabilidade e comportamentos que diziam respeito as formas de viver e estar numa cidade que se pretendia afirmar como moderna e cosmopolita (SPINOSA: 2006).

O cultivo do gosto pelo cinema, o consumo de produtos importados e a prática dos meetings e competições automobilísticas dentre outras ações, descrevem muito bem esse contexto em que certos segmentos sociais da urbe procuravam firmar uma imagem de distinção e superioridade social ao partilhar códigos de conduta e valores que julgavam distinguí-los das camadas pobres da capital. ${ }^{4}$

Todavia, a convivência indesejada entre ricos e pobres imposta pelo moderno estilo de vida urbano revelava-se um impecilho para a consolidação de um projeto de cidade essencialmente burguês e americanizado. Fosse pela utilização dos sistemas de transportes urbanos, pelo compartilhamento do cotidiano doméstico com os empregados, pela contratação de serviços prestados exclusivamente por gentes pobres (leiteros, passadeiras, quituteiras, costureiras) ou mesmo, pela criminalidade em expansão em vários pontos da urbe; a cidade se mostrava extremamente heterogênea em sua composição e nas formas de apropriação do espaço citadino. ${ }^{5}$

Era o espaço em que viviam e transitavam sujeitos como o carpinteiroAlexandre Lucena e o ferreiro Manoel Costa, moradores ao Largo do Palácio, 24 e a avenida Conselheiro Furtado, 96, promoveram desordens certa noite de $1920^{6}$; ou como Maria Joanna dos Santos, parda de 33 anos de idade, que se envenenou em via pública. ${ }^{7}$ 
Personagens reais de histórias de vida que se desenrolavam no espaço urbano e que costumeiramente incomodavam alguns indivíduos oriundos das camadas ricas e letradas.

Todas essas situações dificultavam o controle hegemônico da urbe belemita por parte das elites econômicas locais e embora pareça à primeira vista que atingissem tão somente os espaços públicos das ruas ou privados das residências familiares, também se expressavam em outros territórios citadinos, dentre os quais nos interessa analisar o espaço da escola.

Através da narrativa dalcidiana é possível compreender como no ambiente escolar se exteriorizavam conflitos de classe, raça e gênero, muitos dos quais pontuavam a sociedade local entre os anos de 1920 e 1940.

Nesse sentido, enquanto instituição para a qual convergiam meninos e meninas de diferentes origens sociais e étnicas, a escola pública, suas práticas de escolarização e vivências cotidianas davam visibilidade as contradições sociais que permeavam a região.

As inquietações do menino Alfredo com o ambiente escolar, os questionamentos sobre a utilidade daquele saber institucionalizado e as referências ao sonho de educar-se para ascender socialmente, surgem como discussões que possibilitam observar alguns dos conflitos e antagonismos que surgiam nesse processo de conformação social.

Sob este prisma, o registro literário dalcidiano traz à tona percepções do universo escolar como um microcosmo de relações que se assemelhavam aquelas que estruturavam a sociedade paraense.

\section{Os idilios do menino Alfredo em busca do Colégio: Educação, ascenção social e conflitos etnico-raciais nas narrativas dalcidianas}

Em grande parte da obra Belém do Grão Pará, Dalcídio procura mostrar o processo de transformação das representações do menino Alfredo sobre a importância da escolarização. Nesse sentido, transita pelos sentimentos de medo, deslumbre e desejo de aprender os conteúdos escolares até a repulsa pelas mínimas coisas inerentes a rotina do grupo escolar Barão do Rio Branco. Vejamos:

\footnotetext{
"Na sala, contemplando o piano, Alfredo fingia estudar. Folheava a gramática de Paulino de Brito, trazida de Cachoeira. Os verbos, não decorava. As janelas fechadas, por que? O piano pesava, os postais nas colunas desbotavam-se e por que aquela moça na fotografia antiga se era agora D. Inácia? Encaixilhados na parede os dois retratos, bonitos demais para serem o seu Virgilio e a D. Inácia. Bonitos? Não. Nem bonitos nem parecidos. Faziam de conta. E ali em cima do joelho aberto, o ver "ter" sem o "r", "tê", dito nos lábios apenas, tão breve, muitas vezes quase num sopro. E aqui na gramática esse "ter" eram três letras, numa conjugação, e um pretérito e um conjuntivo... Com aquele fastio da gramática e da aritmética do Trajano, envergonhava-se e ao mesmo tempo ouvindo Andreza lhe dizer "tê, três e um é cinco, que o peixe tivesse língua?" $\mathrm{O}$ labirinto das frações o enchia de insegurança, de súbitas covardias. Tinha de prestar exame para o terceiro ano elementar do Grupo Escolar Barão do Rio Branco.",
}

O trecho transcrito registra o encontro simbólico de Alfredo com as obrigações trazidas pela tarefa de estudar na capital. Sob este enfoque, o menino vindo do interior e que aprendera as primeiras letras com um professor particular antes mesmo de ir à escola sente-se inseguro em face dos conhecimentos formais que precisa adquirir. 
Temor e enfado se misturam denotando o distanciamento afetivo entre o ser e o saber, num processo em que a apropriação da educação escolar corresponderia a perda de um conjunto de sensibilidades pessoais e afetivas que o ligavam às suas origens marajoaras e as pessoas que faziam parte desse universo, representadas na obra pela menina Andreza, de pós descalços, origem pobre e cabocla.

Nessa narrativa, o Grupo Escolar Barão do Rio Branco torna-se uma espécie de simulacro daquilo que a educação formal significava e se constituía para o menino: ritualismo, instrumento de ascensão social e construção de identidade. Para Alfredo, a educação da gramática e da aritmética, das letras padronizadas e formalizadas em regras, das soletrações e raciocínios permitiria que superasse a origem mestiça e humilde.

O exame de admissão, por sua vez, assume a conotação de um rito de passagem em que ser aprovado no teste é receber a permissão para ingressar num mundo de inúmeras novidades. A vida em Cachoeira, as brincadeiras ao ar livre e as piadas divididas com os amigos passam a ser lembranças cultivadas com saudosismo pelo jovem parauara.

"Tudo era por não ser mesmo o "Colégio"? Aquele colégio de faz de conta, visto através do carocinho de tucumã, ao pé da montanha? Para Alfredo, estudo era então algo exclusivo do Colégio, em que os verbos e os números entrassem em sua cabeça, como passarinhos na "Folha Miúda", aquela árvore da beira do rio, defronte do chalé.

Saber era como viajar e ali, no 160, não havia viagem, nem no Grupo, montanha ou jogos em pleno jardim onde viessem dar aulas os professores.

Vendo-o com a gramática fechada, pés cruzados, esquecido a olhar o piano, Emilinha advertiu:

Meu anjo, meu anjo, você vai fazer o feio? Assim não passa no exame. Está pensando que é Cachoeira? Tem mesmo vontade de estudar? Olhe os sacrifícios que sua mãe anda fazendo."

Não obstante as apreensões pessoais de Alfredo, o autor da narrativa procura enunciar a existência de outros olhares e representações discursivas acerca da educação escolar. Nesse sentido, Emília Alcântara adverte o jovem estudante sobre a responsabilidade que lhe recaía nos ombros, de fazer jus às expectativas da família e passar no exame de admissão. Ao mesmo tempo, ao perguntar quase em tom afirmativo: _Esta pensando que é Cachoeira?"; a personagem filha dos Alcântara reforça a idéia do distanciamento que existia entre os saberes adquiridos pelo garoto durante sua vida interiorana e a educação que passaria a receber na cidade, no grupo escolar, por meio de professoras formadas que ensinavam um conjunto de conteúdos técnicos e pretensamente científicos.

Essa percepção da escola como um espaço particular de aquisição de saberes que mesmo voltados para formar o indivíduo para o mundo, não dialogam com aqueles conhecimentos que o sujeito traz de outras vivências fora do lócus escolar, está presente de forma constante na obra Belém dó Grão-Pará.

Várias falas de Alfredo, como por exemplo, “...saber era como viajar e ali, no 160, não havia viagem, nem no Grupo...", em conjunto com os discursos de outros personagens do romance reforçam a idéia que a escola pública já oferecia naquele tempo, apenas uma educação classificada posteriormente por Paulo Freire como bancária. E essa educação não dialogava com os saberes que a vida prática dos escolares proporcionava em outros espaços e ocasiões que extrapolavam à esfera do Colégio e da sala de aula. 
De forma semelhante, em "Passagem dos Inocentes" Alfredo comenta sobre os conhecimentos ensinados pelas professoras normalistas na seguinte perspectiva:

\begin{abstract}
"Por certo, a professora nunca viu um laranjal e dele falava na forma de números, riscos, fração... Algum de vocês já chupou uma laranja da Bahia, onde é a Bahia Lamarão? Nem isso indagava a professora. Faltava laranja na aula. Uma boa aula de maracujá faltava. Em vez que laranja ou do maracujá, era: Quem em mil quinhentos e quarenta e nove chegou na Bahia? E isto dos séculos? Tempo contado em cem anos? Era, de verdade, um tempo? Mil quinhentos, mil seiscentos, mil setecentos, mil oitocentos, em MCLVX existam, houve? No desfilar sem conta das regras definições datas e nomes, não era melhor a aula que davam os olhos da professora Maria Loureiro de Miranda? Tudo nos livros e na boca das professoras fazia lembrar a palavra Maternidade na cabeça das velhas parideiras do Ararí. Ensinar era palavrear? Aprender engolir palha? Alfredo não via os objetos de que falavam as lições."
\end{abstract}

O distanciamento do saber escolar das experiências cotidianas entretecidas pelos educandos em sua relação com o mundo e com as necessidades mais prementes de sobrevivência se encontra manifesto nas variadas vozes construídas pelo escritor; e nesse sentido, o questionamento do valor e da utilidade desses conteúdos escolares para a vida prática dos estudantes é reiterado constantemente.

Nesse sentido, ao inserir Belém do Grão-Pará e Passagem dos Inocentes em seus contextos históricos é imprescindível esclarecer que foram obras produzidas em meados da década de 1950, mas reportando-se a uma realidade social e pedagógica vivenciada por Dalcidio Jurandir durante os anos 1920 e 1930.

Sob este enfoque, é sabido que a década de 1920 assinala no Brasil e também na Amazônia uma série de movimentos intelectuais, culturais e políticos nos quais sobressai a tensão entre a realidade agro-exportadora brasileira e as novas demandas de um capitalismo urbano-industrial que se consolidava. Essas emergentes questões políticoeconômicas colocam em cheque certos aspectos da estrutura educacional brasileira, destacando-se o número insuficiente de escolas nas regiões rurais, os métodos de ensino baseados no enciclopedismo e na generalidade dos conteúdos, a desarticulação entre os saberes difundidos na escola e as necessidades do mundo do trabalho. (ROMANELLI: 1998, p. 94)

Nas artes, vários pintores e literatos procuram achar os contornos do que seria uma brasilidade genuína e por isso, produzem obras que consideram eminentemente autóctones, cujas temáticas destacam certa característica que postulam estar entre as mais singulares do brasileiro: a mestiçagem. Esse traço podia ser amplamente encontrado nas camadas pobres e trabalhadoras do Brasil e particularmente, da Amazônia, que se tornam os personagens privilegiados dos romances escritos nesse período (FIGUEIREDO: 2001).

Impõe ainda esclarecer que Dalcídio possuía militância no Partido Comunista e voz ativa dentre a intelectualidade considerada de esquerda na região, dialogando com nomes como Bruno de Menezes, Jacques Flores, Jorge Amado, Zélia Gatai, Guimarães Rosa, Cecília Meireles, dentre outros. (FURTADO, 2002)

Esse trânsito entre a "vanguarda" artística nacional aliada a sua posição políticopartidária e ainda, conjugada a uma atuação significativa na área educacional paraense, como inspetor de ensino e secretário da Revista Escola, órgão do professorado estadual, explicam várias de suas opções narrativas, destacando-se as constantes menções que faz à 
condição cabocla, interiorana e à origem proletária de Alfredo, para quem a aquisição da educação escolar tornava-se sinônimo de ascenção social, ${ }^{11}$ como se vê no trecho seguinte:

"Fim do mês, entrava em casa com um distintivo de metal preso a uma fita verde-amarela.

_. Mas que é isso no peito? Condecorado? Quadro de Honra? E chegado ontensinho do mato, esse tio-bimba, meu Deus! Ó Emília! Mas já se viu? Assim acaba general."

Observe-se que no romance, a freqüência ao Grupo Escolar -porta de entrada das camadas pobres na educação primária estatal- correspondia a uma etapa de um percurso mais amplo de escolarização almejado por Alfredo, cujo patamar final era o ingresso no Colégio, ou seja, na educação secundária, humanista e científica que possibilitava afastarse dos cursos profissionais, costumeiramente freqüentados pelos filhos dos segmentos mais pobres (RIBEIRO, 1998).

Importante destacar que não é sem incômodo que Dalcídio Jurandir dá voz a Alfredo e o seu desejo por escolarizar-se num Colégio da capital do estado. A escola (pública) é apresentada como um espaço da ordem e da disciplina, essencialmente burguês e de formação de valores burgueses; muito embora, na comunidade escolar composta não apenas por alunos e professores, possam ser encontrados sujeitos das mais diversas origens e condições sócio-econômicas.

"Na Generalíssimo Deodoro, estava o prédio que Alfredo julgou digno
dum colégio, com gradil e portão, no meio de uma larga área de
recreio. Um homem escuro, maneta, manga inútil no bolso do paletó de
casimira, esbravejava contra os moleques que haviam trepado nas grades
do jardim, para retirar um papagaio. Era o Grupo Escolar Barão do Rio
Branco. A entrada o busto do Barão. O maneta era o porteiro, veterano
de Canudos, como informou D. Emília, recebeu os dois com voz
encatarrada e impaciente. Logo assomou, alta, cinzenta, da cabeça aos
pés, cabelo, rosto, vestido, sapato e a própria voz, a espartilhada
Senhora Diretora. Da porta defronte, uma menina, num relâmpago
espiou. Outra arrisca um rabinho do olho certeiro no coquinho pelado de
Alfredo. E aquele zumbido das aulas, embaixo e em cima, inundou
Alfredo de uma súbita decisão de passar no exame, arrepednido de não
ter estudado mais. Receou que as questões de aritmética fossem além das
que lhe dava o professor Chiquinho." 13 (grifo nosso)

Mais uma vez o temor de que os estudos e conhecimentos pregressos não fossem suficientes para lhe assegurar a aprovação no exame de admissão se mostra uma das principais preocupações de Alfredo em quase metade da obra. $\mathrm{O}$ fato de sua experiência escolar anterior compreender saberes adquiridos num contato maior com a terra, o meio ambiente e o espaço aberto do campo, dizendo respeito a uma realidade de escola encravada no meio rural amazônico, em região de beira de rio, de salas de aula com pouca infra-estrutura, de professores que fazem parte da comunidade afetiva mais próxima do educando, é tratado no romance de forma ambígua, oscilando entre o saudosismo e a denúncia política.

Por outro lado, a cultura material da escola, os objetos, o espaço-arquitetura, os recursos didático-pedagógicos são questões importantes na construção das imagens simbólicas sobre o estudar e os saberes escolares. Assim, estar instalada num prédio imponente com gradil e portão concede status e respeitabilidade à escola da capital, 
diferentemente da escolinha de Cachoeira onde ministrava aulas o professor Chiquinho. Percepção reiterada no trecho de "Passagem dos Inocentes" em que Alfredo compara sua condição de estudante do Barão do Rio Branco com o de outros alunos de escola pública, especialmente do Grupo Escolar Doutor Freitas, que se localizava em área suburbana da cidade.

"No seu caminho para o Barão, passava pelo grupo escolar do largo de Santa Luzia, o Doutor Freitas, e espichava o beiço: esse um aí? Coitado. Não tinha a boa presença do Barão, este sim, recostado nas mangueiras do fundo; nem a escadaria de pedra branca nem na entrada, de pedra branca, o busto do Barão."14

O busto do Barão que dava nome ao grupo escolar também é referido com ênfase em "Belém do Grão Pará"; o globo, a mesa da professora e o quadro negro são outros objetos importantes e que tem o porquê de serem mencionados nos textos, na medida em que auxiliam a compor o ideário da época a respeito do que seria uma boa e respeitável escola.

"Entrou na Sala do terceiro ano, um pouco surdo, sem ver ninguém, embora sentindo à sua volta aquele numeroso e miúdo olhar da meninada. O quadro negro pareceu-lhe daqueles panos que lhe encobriam o rosto quando adoecia dos olhos. E o globo, na mesa, intimidou-o, fazia-o mais menorzinho que a formiguinha ali na bainha do vestido de d. Emília. Abaixou-se, tirou a formiguinha. Uma voz de mulher assumia proporções de um brado ecoando na sala, no edifício, no coração do menino, como se avisasse: "não passarás, não passarás!". (...) Prestou exame no meio do zumbido geral. E para espanto de Emília Alcantara, pois não passou?" 15

Além dos aspectos físicos do ambiente escolar, as características da relação entre professor-aluno são evidenciadas na escrita dalcidiana como pautadas no distanciamento afetivo e na valorização da cultura letrada enquanto elemento de afirmação da autoridade do Mestre sobre o educando.

Paralelamente, a preocupação com a autodisciplina docente e com a disciplina escolar, o cuidado com a apresentação pessoal por parte das professoras e o apego às formalidades, somados a excessiva ritualística presente no cotidiano escolar, a repetividade dos exercícios e a previsibilidade das ações pedagógicas levam ao desapontamento do menino Alfredo com estudos. Fato que na verdade representa o próprio desencantamento do autor com a educação escolar estatal, fundada em métodos que ele reconhecia como superados.

“Alfredo, no Grupo, habituava-se ao desapontamento daquele estudo. Muitas
vezes, esquecidamente, ficava a olhar a espartilhada diretora, as professoras, a
captar aquele perfume delas, o esquivo e proibido encanto em quase todas. As
notas que elas anunciavam alto, os ralhos, o começo de raiva, a impaciência de
uma, o sorriso disfarçado atrás da mão, vestidos, flores na mesa, bolsas, leques, o
espelho de repente em que esta professora se mirava e aquela davauma lição de
vaidade, levaram-no a estimar as aulas. Ao seu lado, lamarão, muito educadinho,
muito prestativo. Quando a campa batia, saíam de um só vôo, encontrando-se no
portão com as meninas. Diante delas, Alfredo se tornava tímido, quase assustado,
até mesmo perante a que colecionava santinhos. Hinos que cantavam, campa das
horas, leitura em voz alta, o soldado de Canudos, maneta, agora um general,
como porteiro, tudo já fazia parte de uma vida velha, quase sem surpresas, por 
momentos, aborrecida. E nele jaziam restos do Colégio perdido, com Andreza também no meio, com suas cartas."16

O desapontamento do personagem corresponde em grande medida às inquietações que Dalcidio Jurandir nutria em relação ao modelo escolar vigente na época em que começou atuar na área da educação. Esse ponto de vista é reforçado ao examinar-se o teor de um artigo que escreveu para a Revista Escola, em 1935:

"A primeira coisa que se ensina á creança é o dever com a lettra grande. Mas dever? Sim, um dever que é a ferrugem deprimindo, corroendo e destruindo o vigor, a alegria e a saúde das creanças e dos adolescentes. $\mathrm{O}$ que se deve fazer da creança é uma criatura humana. A educação não tem sido mais do que um processo policial. Policiar é sempre mais fácil do que educar. Por que educar é exigir a pensar e Anatole France dizia que muita gente não gostava do Hamleto porque o merencoreo príncipe obrigava a pensar...Educar é construir e hoje o processo é destruir e conservar em poeira, as raridades inúteis ou ferozes como o Dogma, o Preconceito, o ensino religioso e o collarinho de pontas viradas... ${ }^{17}$

Entre o discurso real e o ficcional sobressai a angustia por mudanças que alterem o âmbito da escola pública e os saberes por ela ensinados. Nos romances aqui analisados, o enfado e o cansaço diante da rotina escolar passam a integrar as falas de Alfredo e assim o micro-cosmos social que constitui o grupo escolar torna-se uma realidade a ser criticada.

O desinteresse com as aulas, a perda da admiração pelas professoras e seus trejeitos, a insatisfação com os exames e até mesmo a diminuição da empolgação com as condecorações recebidas permitem pensar algumas problemáticas relativas às práticas pedagógicas desenvolvidas nesse período.

As críticas dalcidianas sobre os programas de ensino e metodologias adotadas pela escola do período articulam-se aos inumeros debates em torno da necessidade de abolir-se definitivamente uma educação republicana instituída sob a influência positivista e baseada na repetição e memorização dos conteúdos.

Regionalmente, ao se analisar os programas das disciplinas escolares do curso primário notamos os resquícios dessa pedagogia positivista. Leia-se o conteúdo do programa de Português para o terceiro ano primário, a ser ministrado nos Grupos Escolares belemitas:

" $3^{\circ}$ anno - Leitura corrente de prosa e verso.

Execícios Oraes - Exercícios de invenção.

Composição suggerida por um quadro ou estampa e desenvolvida mediante orientação do professor, primeiro oralmente e, depois de muitos exercícios, por escripto.

Estudo mais desenvolvido do substantivo e do adjetivo. Genero, numero e grau.

Noções do pronome e do verbo.

Conjugação dos tempos simples dos verbos TER e HAVER, SER e ESTAR, bem assim dos tempos simples dos verbos regurales dos três paradigmas.

Estudo succinto das palavras invariáveis

Estudo prático da alteração morphica das palavras pela mudança do gênero e do numero. 
Exercícios escriptos - Dictado de trechos progressivamente mais difficeis que os do anno anterior.

Redacção de bilhetes. Exercícios de memória - Recitação de monólogos, diálogos, fabulas e outros trechos em prosa e verso."18

Exercícios orais, exercícios escritos e exercícios de memória se voltam basicamente para a fixação de um conteúdo previamente fornecido e não para a reflexão ou crítica sobre o mesmo. O desenvolvimento das duas competências básicas do educando (falar e escrever) deve ser dirigida pelo professor para a formação de sujeitos capazes de expressar-se escorreitamente na língua materna, aplicando as regras gramaticais e ortográficas.

É a partir do momento que o menino Alfredo passa a enfadar-se com essa educação que lhe é concedida no grupo Barão do Rio Branco que surgem outras vozes no romance que anunciam saberes e conhecimentos produzidos fora do ambiente escolar; como por exemplo, o Cara Longe, taberneiro da Passagem dos Inocentes, conhecedor da vida alheia e dos segredos etílicos capazes de curar os mais diversos males.

Sobre a relação entre esses dois espaços de transmissão de saberes podemos perceber como a vida além dos muros da escola permite trocas culturais e o aprendizado de lições que extrapolam a esfera das teorizações feitas nas salas de aula dos grupos escolares. Senão vejamos:

“Aquele balcão ali na Bôca, com o Cara-Longe, esguinchava a peçonha, a légua e meia. Todos fossavam a vida do próximo; do mundo só viam o imundo, em meio de suas risadas e de jacurututu.

Alfredo balançava a garrafa, oh! Que nojo da metade desta Inocentes. Ali na taberna, bastava meia hora, crescia um ano. Em que se acabava o colégio ao pé da montanha." 19 (grifo nosso)

Em outras palavras, ao saber formal recai a caracterização de espaço onde impera a valorização de uma cultura geral, afastada das vivências cotidianas de seus alunos, elitista e de difícil acesso para o segmentos mais pobres. Veja-se o exemplo da menina Antonica, nascida e criada em Cachoeira, cujo sonho era tornar-se professora normalista, mas que contenta-se em permanecer no Marajó por entender que não preenchia os requisitos econômicos e sociais para aventurar num estudo na capital do estado.

“_Estudou muito? Fração conhece? Viu lá em Belém, o Gentil, o colégio? As moças de uniforme? A Escola Normal? A menina perguntava muito desembaraçada.

__Sim, que era, era de mea escolha a Escola Normal, isso há cinco anos. Mas ah, aqui na Areinha, mamãe pode? Eu uma professora mas quando...Ah meu balão! Vento não me assopre! Eu quem sou eu."20

Ao questionar "Eu quem sou”, a personagem deixa entrever as dificuldades que as camadas populares enfrentavam para assegurar os estudos formais dos filhos. Desde a insuficiência do número de estabelecimentos de ensino no interior até o custo orçamentário que ter um(a) filho(a) "exclusivamente" estudando impunha.

$\mathrm{O}$ distanciamento entre a escola e as classes populares mostra-se em certos momentos dos romances quase intransponível. Se por um lado a escola era um sonho almejado pelas pessoas simples da região, na prática custava muito caro, além de corresponder a um processo de formação alijado do contexto social. 
Esse aspecto é problematizado nas falas que se entrepõe durante certo debate caloroso travado por dois personagens que surgem nas últimas páginas de "Belém do Grão Pará": Seu Lício, um amigo próximo da família Alcântara é um gráfico aposentado, pardo e de origem operária, que de forma auto-didata por meio da militância política tem acesso a discussões de cunho filosófico. Já Viriato ou viriatinho, como era chamado por Emília Alcântara, é um advogado de porta de cadeia, migrante fugido das secas do Maranhão que se torna noivo de Emília Alcântara. Entre eles a distância trazida pelo acesso ao saber formal, legitimado pelo discurso competente, mostra-se intransponível.

"Cortando a palavra de seu Lício, o advogado, afinal, cessou um instante de levar o garfo à boca, a fim de usá-lo, um minuto, para uma opinião. Isaura instigou o duelo.

Conhece o socialismo de Cátedra?

Entalou o garfo nos dedos num desafio de espadachin: as idéias de seu Lício não eram mais novidade, conhecia de suas aulas de direito, vinham de Platão, ou ainda não sabiam? Certo de ter ganho a primeira estocada, pousou, generoso, a espada no prato:

_E revoluções, destesto. Basta a francesa. O vodka, já provei. Queimoume o estômago. Uma reforma social, feita em doses, por homens capazes, ainda vá lá... Mas cadê a capacidade? No Brasil? Mas quando que o Brasil deixou, deixará de ser o país das Arábias?

Seu Lício roçando o cabo do garfo no peito, aparou a cutilada:

_ Somos irreconciliáveis, irreconciliáveis, doutor, a sua faculdade de direito e a minha oficina de encadernação, Doutor. ${ }^{21}$ (grifo nosso)

A distância existente entre o gráfico e o advogado não decorre apenas das condições de escolarização a que ambos foram submetidos ao longo da vida, é também um abismo social que tem origem na própria condição de classe ocupada por eles. O primeiro é um proletário, enquanto o segundo embora de origem pobre, conseguiu superar as dificuldades econômicas e ocupar uma posição que possibilitava certo prestígio social.

Essa distinção obtida a partir do exercício de certos ofícios e profissões é anunciada em alguns momentos das narrativas dalcidianas. A figura da engomada normalista que residia na Passagem Mac-donald e portava-se de modo diferenciado dos demais moradores do lugar ilustra bem essa discussão:

"No amanhecer de quarta-feira, Alfredo folheava a Paulino de Brito, já sabendo que a Arlinda entre as estacas bebia o caribé da d. Romana. Não quis ver o cada vez mais pálido caldereiro sair nem a magra e altiva normalista para ganhar um cumprimento. Seu pensar estava no passeio, da senhora Quarta-feira.",22

Outra situação interessante que indica a percepção da função da educação escolar como instrumento de construção das identidades sociais, que possibilitava para aqueles que a conseguiam em sua plenitude o afastamento da pobreza, da rudeza e dos modos de vida dos segmentos iletrados, se refere a um trecho em que seu Lício discursa sob um pedestal evocando a presença do Doutor Moura, político local:

“_Senhores, meus irmãos, aí vem o nosso professor, o nossoengenheiro, que nunca esqueceu de nós. Aí vem quem sentou em banco de academia mas não desdoura de vir aqui roçar no paletó de nossos cotovelos. 
Deixem passar, abram alas para o mestre. Ele tem a treva nos olhos mas a luz no coração.",23

Outras questões, principalmente aquelas relacionadas às origens etnico-raciais e à condição econômica que caracetrizava a identidade do menino Alfredo são evocadas em múltiplas situações narradas nos romances Belém do Grão Pará\&Passagem dos Inocentes. $\mathrm{O}$ fato de ser filho de mãe negra e pai branco, fruto do amaziamento entre eles, filho de uma segunda união não registrada em cartório importava significativamente para o garoto que deseja mostrar a família seu valor por meio do sucesso nos estudos.

Enquanto nos primeiros romances ("Marajó"\& "Três Casas e Um rio") Dalcidio Jurandir procura demarcar a identidade de Alfredo com base na sua distinção em relação aos demais meninos pobres de cachoeira, posto que diferentemente deles frequentaria o colégio na capital, adquirindo um saber que esses outros moleques não poderiam acessar; em "Passagem dos Inocentes" o mal estar do estudante com suas origens raciais e sociais eclode de maneira explícita, sendo a escola o espaço que esses conflitos se intensificam:

"Escorria da montanha o Colégio sonhado.Este sonho era o que diferençava dos moleques de Cachoeira, o separava dele. Agora despojado do Colégio, sentia-se igual aos moleques, qualquer menino de Grupo Escolar. A família Alcântara não acolhia um menino especial e sim este caboclinho que sou euzinho, cabeça rapada, sobrinho de Isaura, a costureira, e esta, filha da tacacazeira do canto da Quintino.

Entre a paixão de estudar e o estudar mesmo atravessava a viagem, os seus novos sentimentos, a perda do carocinho, ou a morte súbita de sua infância?"24 (grifo nosso) formal?

Sob esta perspectiva, poderiamos inquirir: qual era a finalidade da escolarização

Se considerarmos as criticas que Dalcidio apresentava na revista Ensino ao modelo escolar vigente nos anos 1920 e 1930, poderiamos afirmar que a função da escola era formar o homem livre, consciente de sua realidade social e apto a enfrentar os desafios concretos que a vida lhe apresentava.

\footnotetext{
"A concepção da belleza e da verdade ainda não foi ensinada ás gerações. A primeira coisa que se ensina á creança é o Dever com a lettra grande. Mas dever? Sim, um Dever que é a ferrugem deprimindo, corroendo e destruindo o vigor, a alegria e a saúde das creanças e dos adolescentes. O que se deve fazer da creança é uma criatura humana. A educação não tem sido mais do que um processo policial. Policiar é sempre mais fácil do que educar. Por que educar é exigir a pensar e Anatole France dizia que muita gente não gostava do Hamleto porque o merencoreo príncipe obrigava a pensar...Educar é construir e hoje o processo é destruir e conservar em poeira, as raridades inúteis ou ferozes como o Dogma, o Preconceito, o ensino religioso e o collarinho de pontas viradas...,25
}

Não obstante, as narrativas romanescas dos textos analisados nos apontam uma outra educação, bem diferenciada daquela que Dalcidio defendia. Ao descrever os confitos psicológicos e existênciais do menino Alfredo, por meio da narrativa ficcional o literato dá a conhecer o padrão de escola que considerava ser prevalecente na sociedade paraura da época, ou seja, o de uma instituição excludente, de função utilitarista, incapaz de dar conta 
da diversidade e demandas sociais que caracterizavam os sujeitos sociais que a frequentavam.

Paralelamente, devemos considerar que a questão racial emerge como pano de fundo de uma sociedade que desejava branquear-se, mas que tinha como característica uma forte miscigenação racial, num contexto em que as heranças etnicas da negritude não eram bemvistas. Nesse sentido, havia a problemática de que a condição racial de ser negro ou pardo se associava costumeiramente à diversas circunstâncias de caráter econômico, quais fossem, de ser pobre, proletário e iletrado; aspectos assinalados de maneira poética no trecho acima transcrito.

Por outro, a leitura que o persoangem Alfredo faz da presença de um colega de classe que nas suas palavras "estranhamente" estudava no Barão, muito embora possuisse finos modos e morasse num belo palacete de uma bairro chic da cidade, leva-nos a questionar a existência de diferentes modalidades de escolas públicas durante os anos pesquisados. Dessa feita, o grupo escolar parece ser a escola destinada ao ensino dos pobres e dos filhos de trabalhadores; enquanto o Colégio propriamente dito, possui um status superior de instituição que fornecia uma educação superior para a qual nem todos tinham acesso, quer fosse por questões econômicas ou sociais.

Em trecho que Alfredo descreve o amigo Lamarão, morador de uma palecete no bairro de Nazaré e portador de hábitos refinados Dalcidio descreve:

"Quem vivia debaixo daqueles forros reluzentes estar no Barão precisava? Precisava aquele traje de missa, todas as manhãs e sentar-zinho na carteira manchada de tinta, roida nas quinas, e ali de boca aberta, antes atencioso que atento, a cabeça um pouco pensa, como se escutasse só de um lado, a apanhar as cifras e os proparoxitonos das professoras?"

O grupo escolar substitui o sonho do colégio; concretiza o desejo de educação de Alfredo sem grandes alardes ou signficativas impressões. $\mathrm{O}$ que nos leva a pensar: haveria assim uma escola para os populares e outra destinada a atender os segmentos abastados da urbe; ainda que o discurso oficial preconizasse a todos os segmentos acesso á educação pública e gratuita?

\section{Considerações Finais:}

Assim, considerando o contexto histórico em que se passam as narrativas e também as próprias particularidades de formação política de Dalcidio Jurandir concluímos que a grande questão presente em Belém do Grão Pará diz respeito ao fato que a educação pública escolar na época analisada era apreendida como ferramenta privilegiada para assegurar o posterior ingresso do educando numa sociedade de lógica burguesa, diferindo pouco de alguns debates que são colocados até mesmo no tempo presente.

Os métodos utilizados, o formato dos currículos e os discursos oficiais acerca da educação afastavam-na da possibilidade de ser um meio de libertação pessoal do escolar ou de aquisição de saberes dialogassem com as identidades culturais próprias dos alunos. Aspectos muito bem trabalhados pelo literato nas obras analisadas.

Por outro lado, em Passagem dos Inocentes o escritor paraense enfatiza os conflitos subjetivos do menino Alfredo em busca de sua escolarização. Nesse prisma, temáticas relacionadas com questões étnico raciais ou com problemas sociais derivados da condição de pobreza de boa parte da população interiorana do estado surgem de modo latente na obra.

Assim, consoante as narrativas de "Passagem dos Inocentes" educar-se era mais que um desejo de Alfredo, constituindo-se um desafio que teria que vencer apesar de todas as adversidades. 
Porém, o grande problema é que após alcançar a escola tão almejada, os conteúdos ali difundidos se mostravam por demais abstratos e desconectados da realidade social que envolvia o escolar Alfredo. Deste modo, assim como o personagem Alfredo desencantouse da educação pública escolar representada nos romances; Dalcidio Jurandir também decepcionou-se grandemente com o modelo educacional estabelecido no período em que escreveu seus livros, registrando isto de modo expresso para além da linguagem ficcional, através de textos e ensaios publicados em periódicos locais nos quais criticava os termos educativos da época.

\section{Referências}

FARIAS, Fernando Jorge Santos. Representação de Educação na Amazônia em Dalcídio Jurandir: (des) caminhos do personagem Alfredo em busca da educação escolar. Dissertação de Mestrado, UEPA, 2009.

FURTADO, Marlí Tereza. Universo derruído e corrosão do herói em Dalcídio Jurandir. IEL/ Unicamp: Campinas, 2002. Tese de doutorado.

JURANDIR, Dalcídio. Primeira Manhã.Josebel Akel Fares (org.). 2 ed. Belém: EDUEPA, 2009.

Belém do Grão Pará. Belém: EDUFPA; Rio de Janeiro: Casa Rui Barbosa, 2004. (Coleção Ciclo do Extremo Norte)

Passagem dos Inocentes. São Paulo: Livraria Martins, 1953.

Educação. ESCOLA - Revista do professorado do Pará. Directoria Geral da Educação e Ensino Público. Anno I. Setembro de 1935.

Educação é Liberdade. ESCOLA - Revista do professorado do Pará. Directoria Geral da Educação e Ensino Público. Anno I. Setembro de 1935. p. 43-45.

CIAVATTA, Maria. Mediações históricas de trabalho e educação: gênese e disputas na formação dos trabalhadores (Rio de Janeiro, 1930-1960). Rio de Janeiro: Lamparina, CNPQ, FAPERJ, 2009.

O mundo do trabalho em imagens- a fotografia como fonte histórica (Rio de Janeiro, 1900-1930).Rio de Janeiro: DP \& A, 2002.

CHARTIER, Roger. A nova história cultural: entre práticas e representações. Rio de Janeiro:Bertand Brasil, 1989.

FIGUEIREDO, Aldrin Moura de. Eternos modernos: uma historia social da arte e da literatura na Amazônia, 1908-1929. Campinas, SP: (s.n), 2001. Tese de Doutorado.

FURTADO, Marli. Dalcidio Jurandir e o realismo socialista: primeiras investigações. Tessituras, interações, convergências. Anais do XI Congresso Internacional da ABRALIC. São Paulo: USP, 2008.

LOPES, Eliane Marta Teixeira. (org.) 500 anos de educação no Brasil. $3^{a}$ Ed. $1^{a}$ reimp. Belo Horizonte: Autêntica,2007.

NUNES, Paulo. Aquonarrativa ou o encharcar-se na poética de Dalcídio Jurandir. Texto apresentado no I Colóquio Dalcídio Jurandir, promoção UFPa/Unama, em novembro de 2001, em Belém. (mimeo)

O Ensino. Revista Mensal de Pedagogia e Literatura. No 11. Maio. 1919. Ano II. Pará Brasil. $2^{\mathrm{a}}$ Phase. Officinas e redacção Instituto Lauro Sodré.

RIBEIRO, Maria Luísa Santos. História da Educação Brasileira. 15 Ed. (revista e ampliada). Campinas/SP: Editora Autores Associados, 1998. 
ROMANELli, Otaíza de Oliveira. História da Educação no Brasil. $9^{a}$ ed. Petrópolis. Vozes, 1998.

STEPHANOU, Maria \& BASTOS, Maria Helena Câmara. (orgs) Histórias e memórias da educação no Brasil. Petrópolis, RJ: Vozes, 2005 (Vols. II e III)

\section{Notas:}

${ }^{1}$ Cachoeira do Arari, município da Ilha do Marajó localizado na margem esquerda do Rio Arari.

${ }^{2}$ Compunham o núcleo familiar dos Alcântara: D. Inácia, a matriarca que no passado pertenceu a Liga Feminina Lemista; Virgílio Alcântara, ex-administrador do Mercado Municipal e funcionário da Alfândega; Emília, a filha única, balzaquiana e que não conseguia arrumar um bom partido para casar-se; e Libânia, menina vinda do interior para servir de empregada da família.

${ }^{3}$ Essa expressão era usada para designar exatamente os migrantes interioranos que aportavam em Belém e desconheciam os códigos de comportamento nutridos pelas gentes do lócus urbano.

${ }^{4}$ Jornal Folha do Norte, 25 de maio de 1930. Ingressos para sessão de hoje do Estrela Ditosa \& O Máscara de Ferro. Cinema ÉDEN. Às 7 e 1/2 horas e 9 horas. Com Gustav Dissl, Brigitte Helm \& Jack Trevor.

${ }^{5}$ Jornal Folha do Norte. 09 de janeiro de 1920. Repressão á Jogatina.

${ }^{6}$ Folha do Norte, 03 de janeiro de 1920. Os pertubadores do socego público.

${ }^{7}$ Folha do Norte, 05 de janeiro de 1920. Fls. 04.

${ }^{8}$ Jurandir, Dalcidio. Belém do Grão Pará. Belém: EDUFPA; Rio de Janeiro: Casa Rui Barbosa, 2004. (Coleção Ciclo do Extremo Norte). p. 109.

${ }^{9}$ JURANDIR, Dalcídio. Op. Cit. p. 109-110.

${ }^{10}$ JURANDIR, Dalcidio. Passagem dos Inocentes. São Paulo: Livraria Martins, 1953. P.115-116.

${ }^{11}$ Conforme Farias (2009, p.85) "diante das vivências que tem, principalmente as relacionadas a uma educação das classes populares, Dalcídio sente-se na 'responsabilidade' de representar, amargamente, grande parte do povo amazônida que sofre e luta para sobreviver, 'famintos por saber', como é o caso do marajoara Alfredo."

${ }^{12}$ JURANDIR, Dalcídio. Belém do Grão Pará. Belém: EDUFPA; Rio de Janeiro: Casa Rui Barbosa, 2004. (Coleção Ciclo do Extremo Norte). p. 125.

${ }^{13}$ JURANDIR, Dalcidio. Idem. p. 122

${ }^{14}$ JURANDIR, Dalcidio. Passagem dos Inocentes. São Paulo: Livraria Martins, 1953. P. 117

${ }^{15}$ JURANDIR, Dalcídio. Belém do Grão Pará. Belém: EDUFPA; Rio de Janeiro: Casa Rui Barbosa, 2004. (Coleção Ciclo do Extremo Norte). p.123.

${ }^{16}$ JURANDIR, Dalcidio. Idem. p. 400

${ }^{17}$ JURANDIR, Dalcidio. Educação. In: ESCOLA - Revista do professorado do Pará. Directoria Geral da Educação e Ensino Público. Anno I Setembro de 1935 Num.5. P. 43-45.

${ }^{18}$ Programmas de ensino. Organizados e mandados adoptar pelo Conselho Superior do Ensino Primário, em 1919. Matéria Portuguez. In: O Ensino. Revista Mensal de Pedagogia e Literatura. No 11. Maio. 1919. Ano II. Pará Brasil. $2^{\text {a }}$ Phase. Officinas e redacção Instituto Lauro Sodré.

${ }^{19}$ JURANDIR, Dalcidio. Passagem dos Inocentes. São Paulo: Livraria Martins, 1953. P. 180.

${ }^{20}$ JURANDIR, Dalcidio. Passagem dos Inocentes. São Paulo: Livraria Martins, 1953. P.28.

${ }^{21}$ JURANDIR, Dalcidio. Belém do Grão Pará. Belém: EDUFPA; Rio de Janeiro: Casa Rui Barbosa, 2004. (Coleção Ciclo do Extremo Norte). p. 502

${ }^{22}$ JURANDIR, Dalcidio. Passagem dos Inocentes. p. 189

${ }^{23}$ JURANDIR, Dalcidio. Passagem dos Inocentes. p.208 e 209. 
${ }^{24}$ JURANDIR, Dalcidio. Idem. p. 113.

${ }^{25}$ Directoria Geral da Educação e Ensino Público ESCOLA - Revista do professorado do Pará.Anno I Setembro de 1935 Num.5

Recebido em: $\quad$ 21/09/2011

Aprovado em: $\quad 10 / 10 / 2011$ 